\title{
Threat to the Conservation of Grey Necked Rock-Fowl (Picathartes Oreas) in Cross River National Park, Nigeria
}

\author{
$1 *$ ODEWUMI, O.S; ${ }^{2}$ ABATCHA, M
}

\author{
*Ecotourism and Wildlife Management Department, Federal University of Technology, Akure, Nigeria \\ **Cross River National Park, Calabar, Nigeria. *Corresponding author Email: OSODEWUMI@futa.edu.ng
}

\begin{abstract}
Threat to the conservation of Grey Necked Rock-fowl (Picathartes oreas) in Okwangwo division of Cross River National Park and support zone community forest were assessed from May, 2016 to February, 2017. Participatory rural appraisal and field observations was adopted. Respondents were interviewed on the various threat factors (direct and indirect) within the study areas. Visits were made to the study area to document observed threats to the habitat and the bird. One-Way Analysis of variance (ANOVA) was used to test for significant differences in the severity of the identified threat factors among the villages and the park staff while t-test was used to test for significance in the direct and indirect threat factors. Nine (9) threat factors/ categories: Farming, logging, water poisoning, hunters camp, charcoal making and hostile behavior (Indirect threats) as well as hunting, trapping (with cage or gum) and egg collection (Direct threats) were identified through interview but six were observed. Farming activities ranked highest (100\%) and more severe, logging was rated as a severe threat (60\%), charcoal making and trapping were rated as moderate both by the villagers and the park staff. However, hostile behavior was rated as less severe (17.5\%) by the villagers and more severe $(70 \%)$ by park staff. Therefore, in order to ensure sustainability of the bird in Nigeria, there should be effective antipoaching patrol measure, conservation awareness campaign and collaboration through community participation.
\end{abstract}

\section{DOI: https://dx.doi.org/10.4314/jasem.v22i4.15}

Copyright: Copyright $\odot 2018$ Odewumi and Abatcha. This is an open access article distributed under the Creative Commons Attribution License (CCL), which permits unrestricted use, distribution, and reproduction in any medium, provided the original work is properly cited.

Dates: Received: 06 March 2018; Revised: 11 April: 2018; Accepted: 20 April 2018

Keywords: Picathartes, conservation, threat factors, National Park, community forest

Myers, (1990), estimated that $15-25 \%$ of all species may become extinct in response to human activity (anthropogenic), by the turn of the century and most of the recent species loss is directly related to habitat loss or environmental degradation. The forests, nevertheless, are reported to be subject to intense poaching activities and habitat degradation, exacerbated by continuous growth of the local population (Oates et al., 2007). Birds, according to Birdlife International (2014), are sensitive indicators of biological richness and environmental trends and fulfill many key ecological functions. Birds, as a group, are good environmental indicators because they have well understood distributions and habitat requirements. They are, in addition, relatively easy to identify and record in the field and can act as flagships for conservation. Birdlife International (2008) stated that birds in particular form the basis of most protected area networks, as well as being an important conservation focus in their own right. Brooks et al., (2001) and Tushabe, (2006) opined that birds can be a highly effective means of setting geographical priorities for conservation in the absence of detailed information on other taxa.
The grey necked rock-fowl (Picathartes oreas) is a medium-sized bird in the family Picathartidae with a long neck and tail. The species has numerous common names, including the grey necked rock-fowl, grey necked picathartes, bare-headed rock-fowl, redheaded rock fowl, blue-headed picathartes, and greynecked bald crow (French, 2006; Thomas, 1991; Olendorf, 2002). It is mainly found in rocky areas of close-canopied rainforest (rugged terrain in these forests covered in large boulders, caves, and gorges) in West Africa from southeast Nigeria to southwest Gabon (Birdlife International, 2011; Fry, 2000). However, in Nigeria, it is only found in Cross River State (Okwangwo division of the park and its support zone communities' forest), the south-eastern corner border to Cameroon (Fry, 2000). The species is widespread in south-western Cameroon, and the country is considered to be the species' stronghold (Awa et al., 2009). The rock-fowl typically chooses to live near streams and inselbergs in its forested habitat. The species is currently faced with an array of threats including habitat loss, predation and hunting especially as its range is becoming increasingly fragmented. Due to its highly specialized requirements for its habitat, its population is very fragmented, and the species is believed to be naturally rare (Harter $e t$ 
al., 2007; Bird life international, 2015). As a result they are currently classified as vulnerable under the IUCN/Birdlife threat criteria and listed in appendix I of CITES, (Bian et al., 2006; Birdlife International, 2011, 2015).

Studies of a Cameroon reserve have revealed that cocoa, coffee and subsistence plots are impinging on the forest, and hunting continues despite its ban. Habitat remains seriously threatened by forest clearance and increasing human disturbance throughout much of its range, and at many sites in Cameroon survives only in poor quality habitat (Thompson and Fotso, 1995). Forest clearance takes place for agriculture, largely crop fields and cocoa plantations (Awa et al., 2009). In many non-protected areas where the species occurs, in Cameroon for example, disturbance is caused by activities such as logging and slash-and-burn agriculture (Bian et al., 200; Awa et al., 2009). In protected areas, encroachment by farmers, hunters and loggers means that these populations are also under threat; and hunters' camps can also disturb the species and lead to abandoned breeding in addition to the removal of eggs and young (Atuo et al., 2014). Adults may be hunted to a limited extent for trade and, on Mt Kupe and the Ebo forest at least, it is often caught in spring-traps set for mammals (Bian et al., 2006). The lack of suitable breeding sites, particularly of suitable rocks, may also partly account for its scarcity. In addition, cannibalism and predation probably contribute to low breeding success (Brosset and Erard, 1986; Bian et al., 2006). For example, low nests in Korup are known to be destroyed by chimpanzees Pan troglodytes and drills Papio leucophaeus (Bian et al., 2006). Disturbance resulting from human visits to breeding sites, especially by birdwatchers within the growing ecotourism sector, is becoming a major concern and it can lead to disproportionate effects on breeding success if safe viewing regimes are not put in place (Awa et al., 2009).

As many species are now facing unprecedented reductions in habitat unavailability due mainly to human actions, range-wide habitat analyses are becoming a necessity, particularly for vulnerable and endangered species across political boundaries (Sanderson et al., 2002; Thorbjarnarson et al., 2006). Recent studies (Bian et al., 2006; Awa et al., 2009) have advocated a range-wide assessment of populations, distributions and threats in order to determine the true conservation status of the species. It's become very imperative to carry out this study in Okwangwo division of Cross River National Park and the support zones community's forest in Cross River State, Nigeria. Finally, we aimed to assess the level of human impact on the species and its habitat in order to foster effective conservation action for the species in Nigeria and beyond.

\section{MATERIALS AND METHODS}

Study Area: The Okwangwo Division of Cross River National Park, falls within two local government areas of Cross River State namely Boki and Obanliku. It lies between $6^{\circ} 4^{\prime}$ and $629^{\prime} \mathrm{N} ; 9^{0}$ and $9^{\circ} 27^{\prime}$ E South - East of Obudu with the Eastern boundary extending along the Nigeria - Cameroon border immediately east of Afi River Forest Reserve, It is bordered to the east by Takamanda National Park Cameroon. It is bordered with about 66 Support zones and 3 enclave communities. The Community's forests were as follows; Bashu-okpa, (6 11 N, $913.5 \mathrm{E}$ ). Bashu-Kaku, (6 $11 \mathrm{~N}, 913 \mathrm{E})$, and Butatong, (06’24,13.5N,009 08'50.7E) which falls under Boki Local Government Area of Cross River State. The main occupations are basically farming (the main crops they cultivate which include Cocoa, Cassava, Banana, Cocoyam and Plantain), hunting, black- smiting, and artistry as well as weaving and carving.

Obot (1996) segregated the vegetation of the Okwangwo Division of the Cross River National Park into four different types namely: lowland rainforest in low lying areas; Ridge/Hill forest on the slopes of Mbe Mountain, sub-mountain forest on Obudu Plateau and Savanna woodland in Ikwete hills. Okwangwo Division has about 1,545 documented species of plants in 98 families, some of which are extremely rare, (National Park Service, 1999). These include: Caraoa grandiflora, Dracaena mannii, Irvingia gabonensis, Sterculia tragacantha; shrubs include: Rinorea keayi, Ixora beviflora and Dicranolepis vestita; ferns and lilies include Asplenium preussi and Dropteris manniana while mosses such as Entodon dregeanus, Tnuidium sp., Pilotrichella sp are also present.

This division is also home to the Cross River Gorilla (Gorilla gorilla diehli) as well as 17 other primates. Two new species of butterfly discovered in the park are: Tetrahanis Okwangwo and Thermoniphas barahingam, Chevrotain, Giant pangolin, the Golden Potto or Calabar Angwantibo and Preuss guenon are also some of the mammalian species endemic to the park (Marguba, 2002).

The climate is seasonal - tropical with a distinct rainy season (March - November) and dry season (December - February). Rainfall is heavy up to 4280mm distributed unevenly within the nine months. Ambient temperatures between $14^{\circ} \mathrm{C}-25^{\circ} \mathrm{C}$ are recorded on the highland areas of Obudu Plateau and Sankwala mountains (Obot, 1997). Topography is rugged with many disjoint and connected ridge 
systems, isolated peaks and rock out - crops. However land is generally at elevation $150 \mathrm{~m}$ above sea level (ASL), rising to around $1500 \mathrm{~m}$ in Sankwala Mountains and up to $1700 \mathrm{~m}$ on the Obudu Plateau. The park is well drained by three main tributaries of the Cross River: Oyi, Bemi and Okorn.

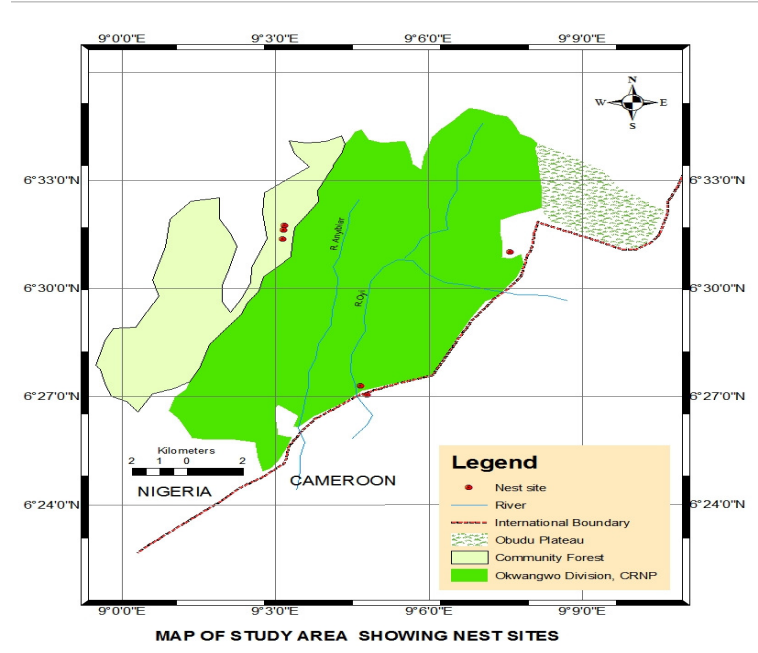

Fig 1: Map of Okwango division of Cross River national park and the community forest

Data Collection: Threat to the conservation of Grey Necked Rock-fowl in Okwangwo division of Cross River National Park Nigeria and the Support zone Community forest were identified through Oral interviews, Focus group discussion as described by Stafford, et al., (2016) and direct field observation according to Odewumi, et al., (2016). Forty respondents, comprising of ten (10) respondents each from four (4) communities (Bashu-Okpambe, Bashu$\mathrm{Kaku}$, Butatong and Belegete) were purposively selected for the interview. These includes the community leaders, leaders of the farmers group and the community youth leaders. Also ten (10) Park staff comprising of five (5) Park rangers and five (5) Research officers were interviewed on the various threat factors: human activities (which may include farming, hunting, trapping, egg collection, logging, charcoal making and hunters' camp) and attitude/behaviour (hostile or not hostile) within the study areas. A conservation awareness poster featuring a colour picture of Grey-necked Picathartes was shown to the respondents to ensure that interviewees could correctly identify the bird and its characteristic mud nest. Direct field observations were carried out by visiting the study area to document the various threats to the habitat (farming, logging, water poisoning, hunters' camp and charcoal making regarded as indirect threat) and the bird (hunting- indirectly measured by presence of spent cartridges, trapping and egg collection). Also, colonies of Picatharthes were located where threat assessment of each colony was done by recording all signs of human disturbance, bush paths, farmlands, hunters camp, bush fire and wire traps within a $40 \mathrm{~m}$ radius of each breeding colony. The threat factors were ranked in the order of their severity as mentioned by the respondents as: less severe (1-39\%), moderate (40-59\%), severe (60-69\%) and more severe (70\% and above). These were coded on four (4) Likert scale (less severe $=1$, moderate $=2$, severe $=3$ and more severe $=4$ ) for analysis. The study was carried out for a period of six months, (3 months in the wet season; May to July 2016 and 3 months in the dry season; December 2016 to February, 2017.

Data Analysis: Data obtained were analyzed by both descriptive (relative frequency, tables, and bar charts) and inferential statistics. Coded data were stored in excel spread sheet prior to the use of One-Way Analysis of variance (ANOVA) to test for significant differences in the order of severity of the identified threat factors within the various villages and the park staff while t-test was used to test for significance in the direct and indirect threat factors.

\section{RESULTS AND DISCUSSION}

The result of the oral interview and focus group discussion survey conducted on threats to the conservation of Grey-necked rock fowl with the local communities and park staff identified nine (9) threat factors/ categories. The indirect threat factors/ categories includes: Farming, logging, water poisoning, hunters camp, charcoal making and hostile behavior. Direct threat factors/categories are hunting, trapping (with cage or gum) and egg collection both in the park and community forest Table 1. Farming activities ranked highest $(100 \%)$ and more severe as attested to in all the villages and by the park staff. Also, logging was rated as a severe threat $(60 \%)$ both by the villagers and park staff. Furthermore, charcoal making and trapping though slightly different were rated as moderate both by the villagers and the park staff. However, there appears to be a disparity on the hostile behavior by the villagers $(17.5 \%)$ to visitors and park staff $(70 \%)$ Table 1 . Test of homogeneity showed a significant difference in the severity of the threat factors as perceived by the villagers and park staff ( $\mathrm{DF}=44 ; \mathrm{p}=0.8639)$ as well as between the direct and indirect threat factors/categories $(\mathrm{t}=-1.4412$; $\mathrm{p}=0.19962)$.

The findings were in agreement with the statements of Sanderson et al. (2002) and Thorbjarnarson et al., (2006) that many species are now facing unprecedented reductions in habitat availability due mainly to human actions. It is also in agreement with 
the findings of many authors that have documented threats to Picathartes at different locations within their range. Notable among them are; Bian et al., (2006), Awa et al., (2009a) who stated that in Cameroon, hunting, traps and snares set for other species, logging and burn farming are among the main threats. They further stated that even in protected areas, encroachment by farmers, hunters and loggers means that the safety of the resident populations cannot be guaranteed. Thomson (2007) also stated that, habitat loss and degradation pose a major threat to the species, especially as its range is becoming increasingly fragmented in Cameroon due to cocoa, coffee and subsistence plots impinging on the forest, and hunting continues despite its ban. The hostility of the local community to the park rangers and researchers claiming that the park took their land and depriving them of their livelihood may be a serious threat as it may prevent effective management of the bird. This hostility if not resolved through dialogue and awareness programme will jeopardize any conservation effort.

Table 1: Severity of the threat factors/categories on conservation of Grey-necked rock fowl by the respondents

\begin{tabular}{|c|c|c|c|c|c|c|c|c|c|c|c|c|}
\hline \multirow{2}{*}{$\begin{array}{l}\text { Threat categories } \\
\text { Indirect }\end{array}$} & & \multicolumn{4}{|c|}{ Communities } & \multicolumn{7}{|c|}{ Park Staff } \\
\hline & $\begin{array}{l}\text { BO } \\
N=1 \\
0\end{array}$ & $\begin{array}{l}\text { BK } \\
\mathrm{N}=10\end{array}$ & $\begin{array}{l}\mathrm{BU} \\
\mathrm{N}=10\end{array}$ & $\begin{array}{l}\mathrm{BE} \\
\mathrm{N}=10\end{array}$ & $\begin{array}{l}\text { Total } \\
\mathrm{N}=\mathbf{4 0}\end{array}$ & Percent & Severity & $\begin{array}{l}\text { Rank } \\
\text { ing }\end{array}$ & $\mathrm{N}=10$ & Percent & Severity & $\begin{array}{l}\text { Ranki } \\
\text { ng }\end{array}$ \\
\hline Farming & 10 & 10 & 10 & 10 & 40 & $100 \%$ & MS & $1^{\text {st }}$ & 10 & $100 \%$ & MS & $1^{\text {st }}$ \\
\hline Logging & 6 & 5 & 7 & 6 & 24 & $60 \%$ & S & $2^{\text {nd }}$ & 6 & $60 \%$ & S & $3^{\text {rd }}$ \\
\hline Water poisoning & 2 & 2 & 3 & 3 & 10 & $25 \%$ & LS & $6^{\text {th }}$ & 4 & $40 \%$ & M & $7^{\text {th }}$ \\
\hline Hunters camp & 2 & 2 & 3 & 1 & 8 & $20 \%$ & LS & $7^{\text {th }}$ & 5 & $50 \%$ & M & $4^{\text {th }}$ \\
\hline $\begin{array}{l}\text { Charcoal making } \\
\text { Behavior }\end{array}$ & 5 & 4 & 4 & 4 & 17 & $42.5 \%$ & M & $3^{\text {rd }}$ & 5 & $50 \%$ & M & $4^{\text {th }}$ \\
\hline $\begin{array}{l}\text { Hostile } \\
\text { Direct }\end{array}$ & 2 & 1 & 2 & 2 & 7 & $17.5 \%$ & LS & $8^{\text {th }}$ & 7 & $70 \%$ & MS & $2^{\text {nd }}$ \\
\hline Hunting (gun) & 4 & 3 & 4 & 2 & 13 & $32.5 \%$ & LS & $5^{\text {th }}$ & 2 & $20 \%$ & LS & $8^{\text {th }}$ \\
\hline $\begin{array}{l}\text { Trapping/ } \\
\text { capture }\end{array}$ & 4 & 5 & 3 & 5 & 17 & $42.5 \%$ & M & $3^{\text {rd }}$ & 5 & $50 \%$ & M & $4^{\text {th }}$ \\
\hline Egg collection & 2 & 2 & 1 & 1 & 6 & $15 \%$ & LS & $9^{\text {th }}$ & 2 & $20 \%$ & LS & $8^{\text {th }}$ \\
\hline
\end{tabular}

The field observation conducted recorded only six threat factors/categories in the study areas. However, logging and charcoal making was not recorded in the park while hunters' camp was not recorded in the community forest during the study period (Table 2). Other threats identified during oral interview and focus group discussion such as water poisoning, egg collection and trapping were not recorded during the survey. Farming activities on going around the nesting site of the rock-fowl, revealed that, forest clearance for maize/cassava was more common $(42 \%)$, followed by cocoa plantation $(36 \%)$ and plantain/banana plantation (18\%) and oil palm plantation (4\%) Figure 2. Also, live capture/trapping of the bird is majorly being done with either cage traps or gum traps Figure 3.

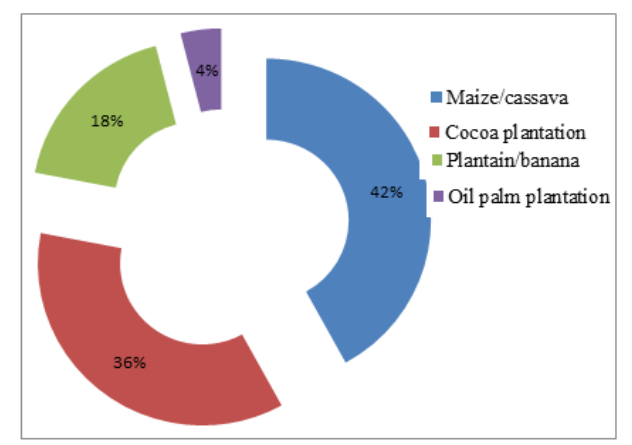

Fig 2: Percentage frequency of crops grown in Grey necked rock fowl habitat
Farming was the most severe threat factor as stated by the respondents and as documented during the field work. This in conjunction with logging and charcoal making as well as the practice of shifting cultivation has put much pressure on the habitat in the community forest while there has been great encroachment into the park. This implies that Grey necked rock-fowl's habitat is seriously threatened by forest clearance for agricultural and other activities as well as encroachment into the Park. These menaces if not checked properly might, have an adverse effects on the bird's preferred habitat and they will have no option than to move to Cameroon. This is in tandem with the report of Thompson and Fotso (1995), Thomson (2007), that forest clearance mainly takes place for agriculture, largely crop fields and cocoa plantations and in many non-protected areas where the species occurs, in Cameroon for example, disturbance is caused by activities such as logging and slash-andburn agriculture. Also Bian et al., (2006); and Awa et al., (2009b) stated that, in protected areas, encroachment by farmers, hunters and loggers to the habitat of grey necked rock-fowl's means that the populations of the Picathartes oreas are under threat. This also support the statement by Ezealor, (1997), that the entire Cross River National Park has 3 enclaves and bordered with 66 support zones communities whose population are at increase leading to the demand for more farmlands for food and cash 
crop productions coupled with hunting, fishing and shifting cultivation being practice by the communities, which are now posing a serious threat to the Park's ecosystem and the fauna and avifauna species there in. The observation of hunters' camp at the nesting sites of the bird potent great danger to the bird because the activity there may make them abandon the site which mean the breeding season is a waste. This is in accordance with the statement by (Atuo et al., 2014; Bian et al., 2006) that hunters' camps can also disturb the species and lead to abandoned breeding in addition to the removal of eggs and young. In addition, Thomson, (2007), reveals that, hunters sheltering in the rock-fowl's nesting caves have been known to kill and eat adult rock-fowls.

Table 2: Observed threat factors/categories in Grey necked rock

\begin{tabular}{lcl}
\multicolumn{2}{c}{ fowl habitat (Nesting } & sites) \\
\hline $\begin{array}{l}\text { Threat } \\
\text { categories/factors }\end{array}$ & Park & $\begin{array}{l}\text { Community } \\
\text { Forest }\end{array}$ \\
Indirect (Habitat) & & \\
\hline Farming & & \\
Logging & $\mathbf{X}$ & $\sqrt{ }$ \\
Water poisoning & $\mathbf{X}$ & $\mathbf{X}$ \\
Hunters camp & $\sqrt{ }$ & $\mathbf{X}$ \\
Charcoal making & $\mathbf{X}$ & $\sqrt{ }$ \\
Hostile behavior & $\sqrt{ }$ & $\sqrt{ }$ \\
Direct (Bird) & & \\
Hunting (gun) & $\sqrt{ }$ & $\sqrt{ }$ \\
Trapping/capture & $\mathbf{X}$ & $\mathbf{X}$ \\
Egg collection & $\mathbf{X}$ & $\mathbf{X}$ \\
\hline \multicolumn{2}{c}{$\sqrt{\text { =Observe; }} \mathrm{X}=$ not observed }
\end{tabular}

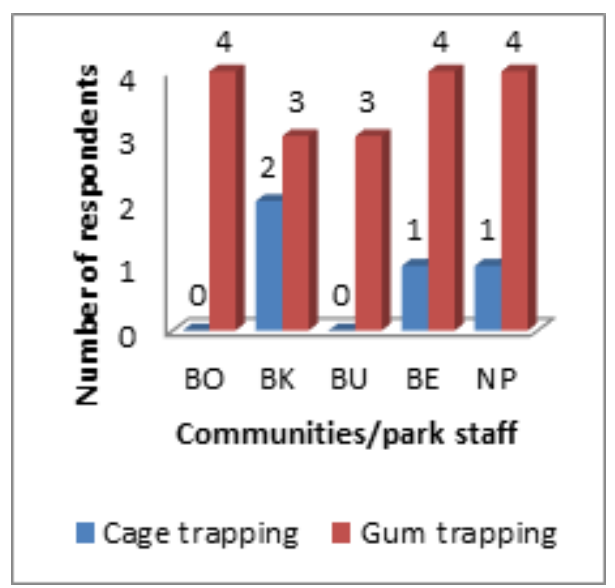

Fig 3 Grey-necked rock fowl Trapping/capture methods adopted by the local communities

Live capture of the bird is being done majorly through the use of gum with few people using cage trap. The use of gum to trap grey necked rock fowl has not been recorded anywhere. However, according to Atuo et al (2016), in Cameroon and other parts of the range of grey necked rock fowl, it has been reported that the bird is caught in spring traps set for mammals and wire snares. Therefore, this is a threat factor that should be stopped if we want to sustain the bird population in the study area. The implication of this trend is that, rockfowl will soon go into local extinction if serious antipoaching strategies and conservation awareness are not adopted by the Cross River National Park and other Conservation bodies to check this trend.

Conclusion: This study has been able to ascertain the fact that Grey necked rock fowl is faced with both direct and indirect threats resulting from human activities and behavior. Therefore, in order to ensure sustainability of the bird in Nigeria, these threats should be addressed through: effective antipoaching patrol measure, conservation awareness campaign to sensitize the local communities on the need for collaboration through community participation and provision of alternative livelihood.

\section{REFERENCES}

Atuo, AF; Ivande, ST; Wala, ZJ; Manu, S; O’Connell, TJ (2016). Current distribution, breeding population and habitat use of the globally threatened Grey-necked Picathartes Picathartes oreas in south-eastern Nigeria: a call for conservation action. Ostrich 87 (2): 1-12. DOI:10.2989/00306525.2016.1179229

Atuo, FA; Ivande, ST; Wala, Z; O'Connell, TJ (2014). Effects of hunting camps on breeding greynecked picathartes Picathartes oreas in south-east Nigeria. Oryx 48: 460-464

Awa, T; Dzikouk, G; Norris, K (2009). "Breedings distribution and population decline of globally threatened Grey-necked PicathartesPicathartesoreas in MbamMinkom Mountain Forest, southern Cameroon". Bird Conservation International 19 (3): 254-264.

Bian, RM; Awa, T; Ndang'ang'a, PK; Fotso, R; Hoffmann, D; Sande, E (2006). International Species Action Plan for the Grey-necked Picathartes Picathartes oreas. BirdLife International, Nairobi, Kenya and Royal Society for the Protection of Birds (The RSPB), Sandy, Bedfordshire, (eds). 2006.UK..pp36

Birdlife International (2004). Birds in Europe: Population estimates, trends and conservation status. Cambridge, U.K. pp 14.

Birdlife International (2008). The impact of Important Bird Area directories. Downloaded from http://www.birdlife.org on 22/11/2017.

BirdLife International (2011). Species factsheet: Picathartes oreas. Retrieved 26 September 2017 
Birdlife International (2012). "Picathartes oreas".IUCN Red List of Threatened Species.Version 2013.2. International Union for Conservation of Nature.Retrieved26 November 2013.

Birdlife International (2013). Birds are very useful indicators for other kinds of biodiversity. Downloaded from http://www.birdlife.org on 22/11/2017

Birdlife International (2016). Picathartes oreas. The IUCN Red List of Threatened Species 2016: T22708119A94149784. Downloaded on 22 November 2017.

Brooks, AP; Abbe, TB; Jansen, JD (2001). Putting the wood back into our rivers: An experiment in river rehabilitation. Third Australian stream management conference: the value of healthy streams, 27-29 August, pages 73-80, Brisbane.

Brosset, A; Erard, C (1986). Les Oiseaux des regions forestieres du nord-est du Gabon. Societe Nationals de protection de la nature, Paris. Vol. 1. Paris.

Ezealor, AU (1997). Important Bird Areas in Africa and Associated Islands- Nigeria.

French, A (2006). "Rock On: Rock Islands Provide Rare Habitat for Rare African Bird" (PDF). Wildlife Conservation (Bronx, NY: New York Zoological Society) 109 (4): 10-11

Fry, C. H.; Stuart, K. and Emil K. U. (2000).The Birds of Africa Volume VI. London: Academic Press. ISBN 0-12-137306-1.

Harter, BB; Matthew, HS (2007)."Notes on breeding and conservation of the Grey Necked Picathartes (Picathartes oreas) in mainland Equatorial Guinea". Ostrich (Grahams town, South Africa: Birdlife South Africa) 78 (1): 97-100.

Marguba, LB (2002). National Parks and their benefits to local communities in Nigeria. Nigerian National Park Service, Abuja. Pp 34

Myers, N (1990). Conservation for the 21st Century Edited by Western David and Pearl Mary Oxford University Press, Oxford and New York, 1989, 365 pp., HB £28.00. Oryx, 24(2), 113-113. doi:10.1017/S0030605300034761
Oates, JF; Sunderland-Groves, J; Bergl, R; Dunn, A; Nicholas, A; Takang, E; Omeni, F; Imong, I; Fotso R; Nkembi, L; Williamson, L (2007). Regional action plan for the conservation of the Cross River gorilla (Gorilla gorilla diehli). Arlington: IUCN/SSC Primate Specialist Group and Conservation International.

Obot, EG; Edet, C; Olory, C; Ayuk, J; Akongke, C (1996). Biological inventory in the Okwangwo division, Cross River National Park. WWF-UK.

Odewumi, OS; Hagher, I; Agbelusi, EA (2015). Effect of Development on Avian Diversity and abundance in Federal University of Technology Akure, South-west Nigeria. Applied Tropical Agriculture 20 (1) 24-30.

Olendorf; D (2002). Grzimek's Animal life Encyclopaedia, (second ed) Faarmington Hills, Mi: Gale Group page 524.

Stafford, CA; Alarcon-Velenzuila, J; Patino, J; Prezoisi, RF; Sellers, W.I (2016) Know your Monkey Identification Primate Conservation challenges in Indigeneous Kichwa Community using an Ethnoprimatological approach, Folio 87: 31-47.

Thomas, J (1991). "Birds of the Korup National Park, Cameroon".Malimbus 13 (1) 11-23.

Thompson, HSS (2007). "Family Picathartidae (Picathartes)". In Del Hoyo, Josep; Elliott, Andrew; Christie, David. Handbook of the bird of the world. Picathartes to Tits and Chickadees. Barcelona: Lynx Editions.

Thompson, HS; Fotso, R (1995). Rockf owl: the genus Picathartes. Bulletin of African Bird Club 2: 2530

Thorbjarnarson, J; Mazzotti, F; Sanderson, E; Buitrago, F; Lazcano, M; Minkowski, K; Muniz, M; Ponce, P; Sigler, L; Soberon, R; Trelancia, AM; Velasco, A (2006). Regional habitat conservation priorities for the American crocodile. Biol. Conserve. 128, 25-36.

Tushabe, H (2006). A Nationwide Assessment of the Biodiversity Value of Uganda's Important Bird Areas Network; Conserve. Biol. 20 (1) 85-99. 